\title{
ONE-POT SYNTHESYS OF 2-AMINOBENZO[B]THIOPHENES AND CYTOTOXIC EFFECT OF THEM AGAINST K562 AND HELA TUMOR CELL LINES
}

\author{
E.A.Popova' , V.M. Boitsov ${ }^{2}$, ' M.L. Petrov' \\ ${ }^{1}$ St. Petersburg State Institute of Technology (Technical University), \\ 190013, Russia, St. Petersburg, Moskovsky prospect, 26. \\ ${ }^{2}$ Saint-Petersburg National Research Academic University of the Russian Academy of Sciences, \\ 194021, Russia, St. Petersburg, Khlopina str., 8/3. \\ ${ }^{3}$ St. Petersburg State University, 199034, Russia, St. Petersburg, Universitetskaya Emb., 7/9.
}

DOI: 10.19163/MedChemRussia2021-2021-415_E-mail: ekaterinaapopova@yandex.ru

Benzo[b]thiophene and its derivatives have a special place among chalcogen-containing heterocycles, since the compounds containing this fragment have a surprisingly wide range of biological activity. Benzo[b]thiophene derivatives possess a wide spectrum of activities, among them substances with anticancer, antidiabetic, antituberculosis, antimalarial, and antifungal activities are known. It should be mentioned that 2-aminobenzo[b]thiophenes have been successfully used to create the selective estrogen receptor modulator (SERM) raloxifene and its analogs. Inhibitors of acetyl-CoA carboxylase and tubulin polymerization were also synthesized on the basis of benzo [b] thiophene.

A row of 2-substituted benzo[b]thiophenes were synthesised according to developed by us protocol, including one pot copper(I/II) catalysed reaction of 4-aryl-1,2,3-thiadiazoles with amines in the presence of potassium carbonate in the DMF medium, and tested for their potential antiproliferative activity against two cancer cell lines. Among them 1-(benzo[b]thiophen-2-yl)-2-ethylpiperidine was the most promising compound against both K562 and HeLa cell lines tested. The obtained experimental data indicate the expediency of searching for pharmacologically active substances among 2-aminobenzo[b]thiophene derivatives [1].

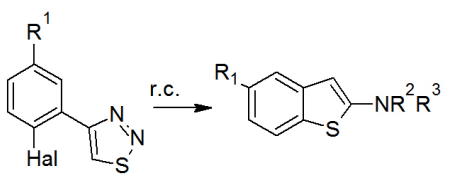

$\mathrm{R}^{1}=\mathrm{H}, \mathrm{Hal}=\mathrm{Br}, \mathrm{NR}^{2} \mathrm{R}^{3}=$ pyrrolidin-l-yl (a); $\mathrm{R}^{1}=\mathrm{H}, \mathrm{Hal}=\mathrm{Br}$, $\mathrm{NR}^{2} \mathrm{R}^{3}=$ 2-ethylpiperidin-1-yl pyrrolidin-1-yl $(\mathbf{b}) ; \mathrm{R}^{1}=\mathrm{H}, \mathrm{Hal}=\mathrm{Br}$, $\mathrm{NR}^{2} \mathrm{R}^{3}=$ morpholin-4-yl (c); $\mathrm{R}^{1}=\mathrm{MeO}, \mathrm{Hal}=\mathrm{Br}, \mathrm{NR}^{2} \mathrm{R}^{3}-$ morpholin-4-yl (d); $\mathrm{R}^{1}=\mathrm{NO}_{2}, \mathrm{Hal}=\mathrm{Cl}, \mathrm{NR}^{2} \mathrm{R}^{3}$ - morpholin-4-yl (e)

Reaction conditions: for (a-d) $\mathrm{HN} \mathrm{R}^{1} \mathrm{R}^{2}, \mathrm{~K}_{2} \mathrm{CO}_{3}, \mathrm{Cul}(20 \mathrm{~mol} \%$ ), $\mathrm{DMF}, \mathrm{Ar}, 4-8 \mathrm{~h}, 80^{\circ} \mathrm{C}$, for (d): morpholine, $\mathrm{DMF}, \mathrm{Ar}, 12 \mathrm{~h}, 80^{\circ} \mathrm{C}$.

\section{References}

[1] E. A. Popova, A. A Kornev, S. V. Shmakov, G. D. Nepochatyi, O. A. Kotyunina, M. L. Petrov, V. M. Boitsov and A. V. Stepakov, Russian Journal of General Chemistry. 2020, Vol. 90, No. 11, pp. 2214-2218. 